\title{
Framing the Islamic Traditionalism Community in Challenging the Social Changes of Modern Society
}

\author{
Rojabi Azharghany ${ }^{1 *}$
}

\author{
${ }^{1}$ Nurul Jadid University, Indonesia \\ *Corresponding author.Email: azharghany@gmail.com
}

\begin{abstract}
The wave of modernization and industrialization affect people's lives. This got a mixed response from the community of Islamic traditionalism led by Kiai. This study reconstructs the framing of Islamic traditionalism community in dealing with the social changes of modern society, through the experimentation of sociological arguments. The social context of this study was in Paiton area with the dual character of Pandalungan society and traditional Islamic religious culture. To analyze the problem, the concept of frames is used in social action. The process of collecting data through in-depth interviews with three leaders of the Islamic traditionalism community and the followers of each community (six people). The choosing of three communities is based on replica models. Analysis of research data is done in an interpretive-reflexive way. The study concludes: first, the community frame of Islamic traditionalism is dominated by community leaders; second, the wave of modernization and industrialization has an impact on the birth of variations of the Islamic traditionalism community in terms of its form, response, and characteristics; third, there is a similarity in responding to social change, namely religious communication strategies to strengthen the goals, narratives, capital and actions of Islamic traditionalism communities, as well as being a tool to break the authority of other leaders; and fourth, the language of religiousness becomes a force in mobilizing the masses and carrying out social transformation.
\end{abstract}

Keywords: Kiai, community, Islamic traditionalism, social change

\section{INTRODUCTION}

This study reconstructs the framing of the Islamic traditionalism community in facing the social changes of modern society, namely through the experimentation of sociological arguments. Analysis in reconstruction is directed to the framing practices that Kiai went through to continue to play a role and take strategic control amid the social change of a dual society. The social context of this study was conducted in Paiton area, particularly at Pandalungan society with traditional and modern patterns in one space (dual society), as well as religious culture of Islamic traditionalism.

The emergence of Islamic traditionalism as an alliance is never separated from the space of social dynamics. Its existence is part of the response to evolving events, contexts, and narratives; sometimes as a counterpoint to a movement, maintaining beliefs and teachings, and the initiative to solve the general problems. The existence of Islamic traditionalism as a counterpoint is often associated with its opposition to the identity of Islamic reformism. The context in Indonesia illustrates the establishment of Nahdlatul Ulama (NU) organization in Indonesia which identified as an alliance of traditionalist Muslims to match the contestation of teachings echoed by reformist Islamist group called Muhammadiyah [1]. Not only in Indonesia, the identity of Islamic traditionalism in India, represented by Sunni group is also confronted by Islamic reformers concerning on the purification of religious teachings [2]. In Australia, the conflict between traditionalist and reformist Islam also occurs despite the limited study of identity [3].

The alliance of Islamic traditionalism is also studied by some researchers related to the teachings, especially today in interpreting religious practices related to national politics, counter-narratives against radicalism and intolerant practices, the development of opposing schools, and social life. The national political attitude of Islamic traditionalism is associated with the principle of moderation and tolerance in the face of policies and social conflicts against the issue of government policies [4]; Its existence is also part of 
social control over the spread of radicalism through guidance, lecture, and dialogue that are part of the arrangement of traditional ritual activities as well as through social media [5] [6]. Islamic traditionalism communities also respond to the development of opposing religious understandings, such as Wahabi that spread to various regions including to the community bases of Islamic traditionalism NU. The attempt of prevention done by NU is shown in the traditional activities such as in pesantren by conducting sholawat community, dhikr and tarekat [7]. The study of Islamic traditionalism that is part of social life is related to the tradition of asking for water prayers and amalan (sacred texts to read) carried out by the community as a proof of faith to solve life problems [8].

The response of Islamic traditionalism to social problems, one of which was contained in the results of the 1979 NU conference on syuun ijtimaiyah. Bruinessen and Wajidi noted, in the beginning of the new order, the movement of Islamic traditionalism led by the Kiai met a deadlock to gain mass support. Later on, the deadlock can be solved with an idea of mass support named syu'un ijtima'iyah [9]. This idea was the engine reviving the movement of Islamic traditionalism as a symbol of civil society power. Kiai's role in driving Islamic traditionalism as a civil society force developed into ideas that were significant enough to influence the way society interpreted Islamic religious practices. The emergence of discourse about emancipatory Islam, transformative Islam, and progressive Islam had such a significant impact especially among young academics and intellectuals [10].

Based on some of these studies, this recent study wants to show a different perspective in studying Islamic traditionalism. The previous research looked at Islamic traditionalism from the point of view of its existence as a counterpoint to a movement, the safeguarding of beliefs and teachings, and initiatives to solve the problem of generality. Meanwhile, this study focuses on the response of Islamic traditionalism toward the social changes in modern society, particularly in Paiton society.

The development of Islamic traditionalism in Paiton driven by Kiai began from the context of social change in the late 19th century marked by the establishment of the forerunner of Pesantren Darul Ulum Paiton. This pesantren is known as the first pesantren in the region. It was then followed by Pesantren Mambaul Ulum in 1928, Pesantren Nurul Qodim in 1947 and Pesantren Nurul Jadid in 1948. Since then, the wave of change in people's lives is tinged with Islamic traditionalism while making Kiai the leader of the tradition replacing the ritual leader in their former beliefs. Initially, the Kiai encountered a severe challenge from the community, especially from the thugs and public's leaders at that time. However, the Kiai was able to show that they were able to conquer the hardships with the knowledge and wisdom [11] [12].

It is not enough just to respond through the tradition movement. Kiai Zaini, founder of Pesantren Nurul Jadid faced the educational change oriented to formal school by establishing Madrasah Ibtidaiyah Agama (MIA) in 1950. He continuously built a formal school with a higher level until 1968. Then, he accepted the initiative of the East Java NU Board to establish the Academy of Da'wah and Education of Nahdlatul Ulama (ADIPNU) which became the forerunner of Nurul Jadid University. On the other hand, several pesantren still survive with traditional teaching and only developed formal education in the 2000s [13].

The changes made by Kiai and their institutions give meaning to the people of Paiton. They believe that the best religious practices/teachings to follow are what have been done by Kiai, namely the Islamic teachings that accommodate the traditions (better known as NU religious traditions) [14]. The existence of formal education prepared by pesantren also has an impact to the way people respond to their lives. They tend toward modernity, although are still attached to NU religious traditionalism [15]. In the economic field, Kiai also teaches how to trade and manage the product, one of which is by introducing tobacco plants, as done by Kiai Zaini. Until now, tobacco plants in the Paiton region became a superior commodity [16].

The second wave of change in Paiton society was marked by the construction of the Steam Power Plant (PLTU) industry which began in 1983. The development of the Java-Bali electricity industry became a strong current of Paiton citizen towards modernization and industrialization. The existence of PLTU not only changed the economic structure of the society which was originally agrarian and informal to be formal, organizational, and modern sectors but also changed the social and cultural structure of its people. Socio-cultural changes are mainly influenced by immigrants both from outside the region and abroad. Sometimes these migrants settle for a certain period and some settle permanently due to the marital factor. The existence of these migrants is the key to the sociocultural change of Paiton society because they tended to bring a more modern lifestyle supported by their modern working climate as well. Urban lifestyles that tend to be elite, individual, and glamour become one of the colors that fill the social space of Paiton 
community, supported by facilities that strengthen the lifestyle, such as the increasing number of housing, play zones, shops, cafes, restaurants, hotels and tourist attractions [15] [17] [19].

The trend of community change towards modernization and industrialization is further strengthened by the establishment of PT. Gudang Garam (a cigarette factory) and several other cigarette industry supplier warehouses such as PT. Bentoel (currently closed), Sampoerna, and Djarum. The presence of these industries seems to be a new 'deity' who can 'guarantee' the sustainability of the society's economic life, while also change the hierarchy of community client patrons. Public trust has gradually been diverted to enjoy dependence on the company even though in daily, the teaching from Kiai is still practiced.

One of the most visible examples in the changing structure of paiton society is related to the assistance of village community development. Before the existence of this industry, village officials have no other choice but to get closer to Kiai, because many assistance programs launched by the government are plotted through pesantren. After the establishment of these industries, village officials and their communities get other sources of income that are large enough from corporate social responsibility (CSR), programs of companies, especially for villages that are in the ring one of PLTU industry. The bargaining position of village officials is strengthened by the village fund program obtained directly from the government.

On the other hand, the impact of this second wave of change in Paiton has overlapped the social institutions i.e. the meeting between traditional and modern communities in one space/region (dual society). The condition of dual society seems to make traditional society a spectator only to the pace of industrialization and modernization. Statistics show the work of Paiton people is still dominated by informal sector activities as farmers, traders, and home craftsmen [20]. In addition, this current rate of inequality affects social problems such as poverty, prostitution, theft, society's internal conflict, gambling, and drug use. This social problem arises because of the unpreparedness of society to face the current changes in modernization along with the lifestyle that occurs around it.

Kiai, as an inseparable figure in the flow of change, takes steps and strategies in response to various social, cultural, economic, and political impacts. They still position themselves as worthy figures to provide guidance and be role models in the uncertainty and problems of life. Kiai is not alone in dealing with social problems. They are supported by the Paiton community, particularly NU organization and Javanese-Madura community. Kia is places at the top hierarchy to guide the Paiton society to follow Islamic traditionalism.

There are three communities of Islamic traditionalism considered as more assertive in Paiton: Nurul Jadid Community led by Kiai Hamid, Syubbanul Muslimin Community led by Kiai Hafidz and Mella' Ate Community led by Kiai Fayadl. Each community has different focus, activities, and followers. Syubbanul Muslimin conducts spiritualreligious practices through sholawat, religious doctrines, and prayers recited by Kiai. Pesantren Nurul Jadid develops the tradition of religious and modern education through pesantren. Meanwhile, Mella' Ate community conducts studies and dialogues covering agricultural, service and environmental materials. These three communities also have different followers. Pesantren Nurul Jadid is followed by educated groups, especially formal ones. Subbanul Muslimin's followers are the lower middle class in both economics and education. Mella' Ate community has followers whose occupations are farmers and fishermen that are into agriculture and services related to policy, relations with corporations and technology innovation.

To analyze the framing of the community of Islamic traditionalism in facing the social changes of modern society, the concept of frames in social action is taken from Goffman's work [21]. He states that frame is "the interpretive framework that enables ones to place, understand, identify, and name the happening incidents around their lives and generally in the world." Frame helps people to seek for lessons from the incidents, then organizes them to be a guidance for every action [22] [23].

Based on Goffman's ideas, Snow \& Benford [24] offer the concept of framing - the process of frame creation - to explain collective action. They argue that framing exists because of collective action. Precisely, social movements are the result of framing and producing a particular frame. In a collective action, frames are created to understand events by simplifying and de-simplification what is happening in "the world out there" and this simplification "aims to mobilize admirers and followers, get supports from the audience, and demobilized opponents" [25] [26]. In other words, the collective frame of action is, first, a set of beliefs and meanings, that are action-oriented and that inspire and legitimize the action; second, a campaign aimed at mobilizing a group of people [27]. 
The frame of collective action was created as part of an effort to negotiate views and attitudes that need to change. This negotiation covers (1) determining what or who is to blame, (2) presenting alternative actions to take, and (3) encouraging the people to change [28]. Benford \& Snow [24] refer to these three as the main roles of framing, which they distinguish as diagnostic framing, prognostic framing, and motivational framing.

Regarding the main task of this framing, the initiators play an important role in "consensus mobilization" and "mobilization of action" [24]. Consensus mobilization encourages agreement on a problem, while mobilization of action leads to movement. It is clear here that collective action is nothing but a movement from the pulpit (mimbar) to the streets, from mind to hands and feet. In today's context, cyberspace and social media are both part of the pulpit as well as the streets contested by various competing frames [29].

Based on the consideration of the approach and theory used, then this study uses qualitative method. The data are collected through interviewing three leaders of the Islamic traditionalism communities and the followers-six people each. The choosing of three communities is based on replica models [30]. The analysis process of research data is done in an interpretive-reflexive way [31], it is through categorization, condensation, cross-check and review of various impressions [32].

\section{DEMOGRAPHY AND SOCIOLOGY OF PAITON SOCIETY}

Paiton District consists of 20 villages and 72 hamlets with a population of 70,191 people that increase continuously due to immigrants. The population shown in Table 1 does not include immigrants who are not recorded in administrative data of residents in Paiton District but settled in Paiton for a certain period for work and education purposes [20].

Table 1. Residents of Paiton District

\begin{tabular}{|l|l|l|l|}
\hline & $\begin{array}{l}\text { Areas } \\
\left(\mathbf{k m}^{\mathbf{2}}\right)\end{array}$ & Population & $\begin{array}{l}\text { Density } \\
\left(\mathbf{p o p u l a t i o n} / \mathbf{k m}^{\mathbf{2}} \mathbf{)}\right.\end{array}$ \\
\hline 2019 & 53.27 & 70.191 & 1.318 \\
\hline 2018 & 53.27 & 65.951 & 1.238 \\
\hline 2017 & 53.27 & 64.952 & 1.219 \\
\hline
\end{tabular}

The majority is Muslim [20] following amaliyah nahdliyin (NU). This can be seen from the existence of the NU Branch Boards that spread in 20 villages and also the $32 \mathrm{NU}$-affiliated pesantren (Interview,
Masduki, Leader Tanfidiyah MWC NU Paiton District, May 27, 2020).

Table 2. Residents' Religion in Paiton in 2019

\begin{tabular}{|c|c|c|c|c|}
\hline Islam & Catholic & Protestant & Hindu & Buddha \\
\hline 70.075 & 85 & 40 & 17 & 5 \\
\hline
\end{tabular}

The socio-cultural practices of the Paiton society are a mixture of NU and Javanese-Madura traditions. This is proven by the habits done by the society such as tingkeban, selapanan or milang are, toron tanah, sholawatan, sarwa, selametan desa, petik laut, walimah, manakiban, tahlilan in every seventh, fourtieth, and thousandth days of person's death and haul. In each event, they always invite religious figures or Kiai, either to lead the ceremony or deliver speech. In terms of socio-economic, the majority of Paiton society worked as hodges, farmers, traders, and fishermen as seen in Table 3 [20].

Table 3. Livelihoods of Paiton District Residents in 2019

\begin{tabular}{|c|c|}
\hline Police/Soldier & 36 \\
\hline Government Officials & 735 \\
\hline Farmers & 4,002 \\
\hline Hodges & 19,467 \\
\hline Traders & 2,072 \\
\hline Home Industries & 179 \\
\hline Fishermen & 1,803 \\
\hline
\end{tabular}

The socio-political color of Paiton society is indicated by the interests of the community, one of which is centered around Kiai. People come to Kiai for various needs, mainly the ones related to the success of trading, harvest, works, and certain official election. They also come for some reasons e.g. health, disease, child plans, and family success [33]. Take an example, in 2019, the candidates of Probolinggo Regency DPRD legislative members, Hafiluddin and Didik Humaidi came to Kiai for asking supports. Hafiluddin's background as a family of Kiai of Pesantren Nurul Jadid, absolutely got the support from the mentioned institution. Meanwhile, Didik Humaidi was supported by Pesantren Mambaul Ulum because of his family background (Interview, Hafiluddin and Didik Humaidi, June 1, 2020). Both successfully occupied the seats of DPRD for the 2019-2024 period.

Culturally, Paiton society consists of a mixture of Javanese-Madurese people. They are similar in terms of the obedience to Kiai. Meanwhile, geographical factor is not the determinant in characterizing the society. The thing that stands out is the legitimacy of religious mainstream driven by Kiai makes Madura society fanatical. Due to the intense interaction with Javanese culture, Kiai Jawa-Madura is more pragmatic compared to Kiai-Kiai Madura [34]. The 
nature of pragmatism also becomes the attitude of the community in addressing various problems, as well as related to interaction with Kiai. Nevertheless, the orientation of cultural values in the area known as Pendalungan, is more toward Javanese tradition-some even say that Madura is the sub-culture where in fact they have some differences [34][35].

In this area, conflict among ethnic groups rarely happens. The dispute that happen or may happen is due to the jealousy in the fields of economy, politic, tradition, not in religion field. This is because in this region Kiai not only becomes a role model, but also a figure who has strong roots in political forces [36].

\section{DIAGNOSTIC FRAMING: DOMINANCE OF COMMUNITY LEADER DISPOSITION}

This discussion directs diagnostic framing in the three communities of Islamic traditionalism in Paiton using the concept of Bourdieu's habitus through his tools in the form of disposition [37]. Habitus is a disposition that directs social actors to perform perceptions and responses in a special way to the surrounding environment. When there is a social dynamic, habitus is what determines the perception and response of Kiai and followers so that they can take action in playing economy, culture, and social. Thus habitus also serves to determine the level of ability of social actors to get a position in the arena [38].

Diagnostic framing in the case of the Community of Islamic Traditionalism in Paiton found a pattern of dominance of Kiai's disposition as a community leader. Partisanship on community goals, perceptions, responses, and social logic built in the community is a continuation of the disposition of community leaders, in this case is Kiai. The tendency of each community to have a different path as a representative is constructed in the habitus of each Kiai and follower with different characteristics. Kiai Hamid through the Nurul Jadid community wants his followers to be ready with all the changing time, so it is necessary to guide mental readiness and skills.

Kiai Hamid wants his community to be systemically organized and networked to familiarize them in facing future challenges in a planned and measurable manner. It is different with the path taken by Kiai Hafidz, the Syubbanul Muslimin Community figure. He focuses on inviting the community to routinely do sholawat and provide religious guidance through lectures.
Kiai Fayyadl, on the other hand, saw that the problem in society is an unfriendly life situation resulting from industrialization carried out by certain elites in the oligarchy group. People who are already in the middle-class position are preoccupied with their respective targets and jobs, so they forget that around them there are mustadlafiin (people who are deliberately weakened by the structure). The Kiais come to the community bringing government projects that tend to be institutional. It is not easily accepted by the community to be aware of building a humanist civilization because they forget the tradition root in society.

Meanwhile, the community followers are present to learn about Kiai's disposition that differentiate the practice in real life. The disposition affects the role and position of followers in a community (the discussion of "positions" will be reviewed specifically in the next sub-chapter). This study captures that the tendency of dispositions in the three communities discussed here signals that mastery of disposition is in the Kiai. Although there is a discussion room and giving opinions on discourses in the community as described in the Nurul Jadid and Mella Ate Community, the follower serves as a distributor of Kiai disposition, representing Kiai speech to be conveyed to others.

Disposition also functions as perception and response [37]. As explained, in the community, the disposition of Kiai strongly influences the followers because there are more opportunities to provide perception and response on events inside and outside the community. In the Subbanul Muslimin Community, for example, the opportunity to perceive and respond to any event can be poured through a oneway lecture to followers. Likewise, in the Nurul Jadid and Mella' Ate Communities, the opportunity to give directions both for the board meeting and the followers can be arranged through the mechanism of a series of events that have been set up in advance.

The thing that distinguishes perception and response is at the level of each community. These three communities have different perceptions and responses to the social problems, generally, and followers, specifically. Kiai Hamid through the Nurul Jadid Community perceives the challenges of the future with a very rapid flow of change that must be responded by institution (system) and network. Kiai Hafidz states that moral problems in society must be solved by bringing people closer to religious traditions, namely prayer and listening to religious lectures packaged as a kind of entertainment. Kiai Fayyadl perceives the problem of classes in society must be responded by bringing back traditions that can anticipate the marginalization of certain classes in society into 
multicultural societies. These responses and perceptions are characteristics of each community and give color to each.

These responses and perceptions are a results of skills, creativity, and a legacy that is constantly repeated in the community by both Kiai and followers. Thus, the personality is completed with ethos, an interpretation framework, social tools, and direction of social orientation. They work together with other individuals to form a social logic reflected in lifestyle and opinion [39].

The source of skills, creativity, and legacy in the Nurul Jadid Community is from religious doctrines, combined with modern traditions of pesantren and education. It is also from the ability to cultivate organizations and applied skills to survive in imagined conditions that will continue to change, thus forming personalities with an independent work ethic, having a framework of interpretation from sources that have been taught with socialist tools. The social orientation catches up with the time development yet maintains the principles. Lifestyle and opinions are highlighted with formal-institutional attitudes balanced by moderation in diversity.

In contrast, the source of skills, creativity, and legacy of religious doctrines and traditions of the Syubbanul Muslimin Community is the love of sholawat combined with modern Islamic art and popular song, as well as utilizing multimedia technology, thus, forming a personality with a work ethic that is willing to sacrifice and to echo the doctrine religion, especially sholawat. The lifestyle side is shown by the crowd and their attributes of sholawat, and the opinions echoed are with sholawat maksiat minggat (staying away from bad behavior).

Similarly, the Mellat' Ate community through its Kiai and followers tend to have sources of perception and response derived from the experiences of oppressed communities. The source is also from liberation theology extracted from Islamic teachings, local wisdom and universal wisdom as well as sociocritical theories aiming at emancipatory, thus shaping one's personality. Those who are militant and sided with the oppressed groups, have progressive interpretation framework with cultural networks, as well as a social orientation direction for real action for solving the problem from the roots. The lifestyle is shown by proletarian tendencies, as well as opinions about progressive Islam.

\section{PROGNOSTIC FRAMING: RELIGIOUS COMMUNICATION AS A STRATEGY}

The study of community framing focuses on the process of action strategy. In this process, framing refers to a deliberation (considerations), utilitarian (designing to be interesting) and also directs to community goals of development. It is done to recruit new members, support mobility, and also obtain resources. Combining the community interests understanding the followers who will become community resources are part of the "frame alignment process" [24].

In the case of Islamic traditionalism in Paiton, prognostic framing leads to religious communication strategies used by Kiai. The three Kiais take different patterns in implementing the religious communication strategy. These differences become each community's characteristics if it is associated with the struggle to get a position in the Paiton community.

The reason of why these three figures use the religious communication strategy is because they live in a religious society. Yet, the analysis is not that simple. The author sees the malleability of religious doctrines to communicate with followers. It means that religious identity can easily, at the same time, become a cultural identity as happens in discourses and symbols dominating in the community [40]. There is no evidence that the influence of religion in any tradition is diminishing. Therefore, this dissertation sees religious communication as the right choice taken by Kiai as a strategy of dominance in the community.

The use of religious communication as a strategy is also seen as a tool to break other authorities that erodes the authority of Kiai. Along with the current second wave of changes that drove Paiton society towards modernization and industrialization. There was a counter authority from entrepreneurs of the PLTU industry and cigarette factories. On the other hand, village policy reforms to village independence in managing funds. They also got the support of corporate social responsibility (CSR) program from the PLTU industry and cigarette factories in the Paiton region for village development. This also changed the hierarchy of community client patrons towards Kiai. The Kiai must choose to face or be committed to the authority of this counterpoint. Beyond the discussion of whether to choose between facing or side by side with these two counter-authority-although these three Kiai choose to use both attitudes, excluding Kiai Fayyad who chooses an attitude of always resistant to the company-Kiai has more bargaining power because they have followers. 
Followers believe that no higher authority has the right to express the religious language but Kiai. At the same time, Kiai is still entitled to talk about the company or the management of the village depending on the capital owned by Kiai about the two arenas. Implicitly in front of his followers, Kiai stated that he has the authority to talk about religion with expressions, for example "When learning about religion, one must not carelessly choose a teacher. Choose the one who is alim, scientific, and an expert of worship". The bargaining power by presenting himself as an authoritative figure using religious communication is in line with Bourdieu's assertion that the language used by social actors represents his authority [41]. Some people are authoritative in disclosing the language and some people are considered dubious in the disclosure of that language.

Now, let us discuss how these Kiais implement religious communication strategies in front of their followers. Kiai Hamid uses discourse on systemic models and the network applied in his community for tafaqquh fiddin (strengthening construction, systems, and mechanisms in religion) and indzar (networking to guide society). This discourse was chosen referring to the Quran Surah at-Taubah [9]: 122. This discourse is often raised and emphasized in meetings with structural officials in the Nurul Jadid Community and directly to followers, so it will appear that the systemic and networked culture in the Nurul Jadid Community is also an identity of religiousness attached to Kiai Hamid and his followers.

Kiai Hafidz, on different side, uses sholawat discourse as part of the civilization of public safety both for world and afterlife affairs. Observing the various tendencies of religious development to date in its cosmic dimension tends to integrate communication in the material order [42]. One of strategies is with sholawat texts. The cosmic dimension of religion has become a tradition that continues to live with society into a religious identity as well as a cultural identity.

Meanwhile, Kiai Fayyadl in the Mella' Ate Community uses texts from the Quran, hadith, and Islamic classic books (known as Kitab Kuning) become the basis in creating the community identity that has a sensitivity to social problems. For example, the Kiai several times conveyed the ideal figures of farmers and fishermen described in the Quran Surah an-Nahl [16]: 10-14 and Surah Saba [34]: 33 discussing about the dependency of social relations dependency involving groups that are weakened and groups that regulate the weak; or Surah an-Nahl [16]: 90 which he used as a reference for explaining the idealization of Islamic political economy (Delivered by Kiai Fayyadl in the study forum of Mella' Ate, July $25,2020)$.

Religious communication is potent because it is effective especially in uniting people's beliefs with their actions, and their ideas with social life. After all, religion assumes the role of ideology as a system of ideas that explains and legitimizes the actions and interests of a particular sector of society [43]. This can be seen from the tendencies of followers, such as Ponirin (follower of Nurul Jadid) who believes that his role in the community as a caretaker. He helps Kiai Hamid to manage the community for a better life of nation and religion. He believes that a disorganized good deed will be defeated by an organized evil. Shakur (follower of Syubbanul Muslimin) wills to follow and assist Kiai Hafidz in organizing the community to get used to sholawat so they will be blessed by the Prophet Muhammad for salvation in the world and afterlife. Huda (follower of Mella' Ate) states that his participation in helping Kiai Fayyadl to develop the community is part of practicing Islamic teachings in activating sensitivity to social problems.

The context of religious communication in the community as a strategy is closely related to language as a practical taxonomy. The use of religious communication in the community has a sacred meaning as expressed at the beginning of this discussion because it is closely related to the question of belief. In general, the practical taxonomy attached to the common sense of followers are the themes conveyed by Kiai related to communicating the meaning of life through teaching; like the survivors and the wretched, the lucky and the losers as well as the noble and the despicable.

The meaning of life establishment is not just anyone can be trusted as a person who has authority in expressing it, because the followers believes, this is dealing with the life problems as a survivor or a wretched person, both in the world and afterlife. That is why a guide is needed.

According to Syakur, although the same theme expressed by different people, followers will not have similar response as when it is delivered by Kiai. This is because from the beginning, the followers trust Kiai as a guide to salvation, not other figures. This is where it becomes a bright spot that Kiai in the community has the discretion to determine the themes given to followers, thus becoming the dominant texts that fill the space of the followers' lives.

The dominant texts raised in the Nurul Jadid Community have a social-educational-political dimension about the generation of fighters who are 
mentally prepared. They have skills to use in a social life based on the doctrine of al wa'yul khoms/Panca Kesadaran Santri (Five Consciousness of Santri). It contains religious awareness, knowledge consciousness, organizational awareness, national and state consciousness, and community awareness. The doctrine is the spirit of all activities in the Nurul Jadid Community. It is obliged for all the staffs to keep this doctrine in every activity. There are control rooms done by the community leaders in describing the principles, through briefing in every meeting held on a limited scale among leaders in community and a large scale with all managers. It is done by studying contextual interpretations written in academic manuscripts and through a discussion led by Kiai Hamid. As a continuity, students are allowed to examine more broadly the values contained in this doctrine, while implementing it in daily life with the direction of managers.

In Syubbanul Muslimin Community, the sociocultural dimension that dominantly is taught to its followers is to love doing sholawat. Besides, they are also learned to do donation and to seek for knowledge from those who are more knowledgeable, especially those who are the descendants (nasab) of the Prophet Muhammad SAW. It is all done to expect the blessing from Allah the Almighty.

In the Mella' Ate community, the dominant texts are economic-political dimensions because the majority of their followers are farmers, fishermen, and workers. When responding to the economic development of Islam, Kiai Fayyadl quotes Surah anNahl [16]: 90. Islamic political economy should move within the limits of justice (' $a d l$ ), humanize (ihsan) and society's prosperity $\left(i^{\prime} t a^{\prime}\right)$ instead of being exploitative (fahsya'), immoral (munkar) and deceived (baghyu) (delivered by Kiai Fayyadl in the study forum of Mella' Ate September 17, 2020).

In summary, the dominant discourse class of religious communication in each community as a strategy that strengthens the Kiai position among followers is presented in Table 4.

Table 4. Discourse of religious communication in the three communities

\begin{tabular}{|l|l|l|}
\hline \multicolumn{1}{|c|}{ Community } & \multicolumn{1}{|c|}{ Discourse } & \multicolumn{1}{c|}{ Dimension } \\
\hline Nurul Jadid & $\begin{array}{l}\text { Systemic } \\
\text { Generation }\end{array}$ & $\begin{array}{l}\text { Social- } \\
\text { Education- } \\
\text { Politics }\end{array}$ \\
\hline $\begin{array}{l}\text { Syubbanul } \\
\text { Muslimin }\end{array}$ & $\begin{array}{l}\text { Imagination of } \\
\text { Salvation }\end{array}$ & Socio-Cultural \\
\hline Malla' Ate & Inequity & $\begin{array}{l}\text { Economics- } \\
\text { Politics }\end{array}$ \\
\hline
\end{tabular}

This difference in discourse and dimensions within the scope of the community reaffirms Bourdieu's view of the interconnectedness of strategy to habitus and the arena. Bourdieu sees strategy as an intuitive product of social actors' understanding of the game rules in a given space and time [44]. Showing the motion of three Kiais in these different communities, it intuitively produces different religious communication because it happens in different spaces. Space that has been formed autonomously through the reciprocal dialectic between habitus and arena (with all structural and position devices) in a relatively arbitrary time is suspected by Bourdieu as an autonomous condition with specific capital and strategy. Therefore, the different characteristics of followers are because of each Kiai. One community and another cannot apply similar discourse because it has different dimensions so this situation produces different symbolic of Kiai power: Nurul Jadid community with a generational discourse that works systemically surrounded by the symbolic power of intellectual and networked Kiai; Syubbanul Muslimin with discourse in the form of salvation surrounded by the symbolic power of a populist Kiai; and Mella' Ate with a discourse of injustice of the ruling elite and businessmen surrounded by the symbolic power of advocacy.

Each of these symbolic powers describes what followers of each community admire on the figure of Kiai and Kiai's ability to adjust between capital and habitus in the community. Kiai Hamid with his ability to organize educational institution called Pesantren Nurul Jadid along with the extensive network in the education and politics fields. This emphasized the discourse domination about system and network in the socio-education-political dimension. Kiai Hafid with his ability to discuss the discourse of salvation through religious doctrines and traditions. He approaches the community in an entertaining way. In this case, the approach is included in the socio-cultural dimension. The characteristics of Syubbanul Muslimin followers are those who refuse to a complicated thinking such as the issues of intellectuals and politicians, thus making Kiai Hafid known as populist. Kiai Fayyadl with his intellectual ability to dismantle the establishment regime along with a network of non-governmental organizations and advocacy groups that can dominate discourse on the inability of rulers and entrepreneurs through the economic-political dimension. The characteristic of his followers is admiring advocacy issues. 


\section{MOTIVATIONAL FRAMING: RELIGIOUS VISIBILITY AS A FORCE}

This discussion provides an affirmation that what occurs in the framing of the community of Islamic traditionalism carried out by Kiai and his followers is a more specific form of religious practices in public spaces. Titus Hjelm [45] revisits the repetitive debate about the 'return of religion' to European public spaces. Hjelm saw that there was widespread confusion between religion and religious practices that had a greater impact on contemporary society. He questions what it means by the 'new visibility of religion'; how religion is contested and renegotiated in the public arena - or rather, in different societies - and what impact this struggle has on society, state, and religion itself. This question was ultimately answered by Hjelm who revealed that what happened to European society is a 'secular return' of religion, in the sense that religion is relevant to public discourse when religion has an impact on social problems or is useful to solve social problems.

The situation of European society that became Hjelm's study was inseparable from the will of the politics currents that affirmed the relationship of religion and public space in the concept of secularization. The existence of religious leaders is needed in connection with the private sphere of faith to solve social problems in a religious atmosphere. So, in European society, religious leader is needed only if it has to do with the problem of faith or in the social framework which is associated with faith.

The concept of secularization echoed in the West was denied by their scientists. Peter L. Berger, the late 20th-century sociologist of religion, who was initially the single most influential proponent of the secularization thesis, later, turned into a spokesman for de-secularization and eventually refuted his own earlier work. In the 1970s, Berger began to question his earlier views on secularization. He later reinforced through his "The Desecularization of the World". In the paper, Berger admits that his secularization thesis was wrong and that the world is as 'deeply religious' as it is [46] [47]. Religious resilience and revival, according to Berger, is a global phenomenon and one should seek secularization in elite spaces rather than in the world. The existence of this paper does not want to debate it, it just wants to assert that the existence of religion, with a different intensity, is inevitable in the midst of society.

The situation that is diametrically different from European society is what happens to the Middle Eastern societies. Some countries in the Middle East such as Saudi Arabia and Iran since the beginning has made Islam the basis of statehood by making religious figures as the leader of country. In some other countries, such as Egypt and Turkey, efforts have continued to overthrow secular power within the framework of the Islamic populism movement [48]. As a result, in Turkey, it succeeded and in Egypt, it failed.

Another thing with the Indonesian context. The efforts to make religion as the state basis since the beginning of the establishment of the Republic of Indonesia always get a stalemate and opposition even from the mainstream of Muslims in Indonesia such as Nahdlatul Ulama (NU) [49]. The existence of religion in Indonesia is as a value in the public sphere to create a civilized life, not as a formal legal in the form of a Sharia state. In this context, religious leaders do not appear in the label of formal leaders of statehood but move in the cultural realm. Religious figures are also the social (cultural) leaders but not as government leaders, although some of them occupy important positions in the government. The existence of religious figures occupying the government, even today it is still a debate because it is considered to neglect the main function of the religious figure as a guide for people [50].

Analysis of religious figure's role in Indonesian context can be observed through social practices that the figure also acts as social leader. Kiai's ability to read the impact of social change around them, gaining appreciation from the community to guide them to ethics as well as a technical handle (the ability possessed by some Kiai) in dealing with the flow of social change that is full with uncertainty. The religious language used by Kiai can solve the problems of his followers, even the worst problems of life- and change them into a flexible, aesthetic, and ontological space through conceptualizing the surrender and patience behaviors, as well as the conceptualization of revival (jihad) that encourages followers to remain optimistic in facing problems. As if to be the cure of all ills, the conceptualization of patience in religious language has changed the dimension of the life chaos into tranquility, while the conception of jihad becomes a powerful lighter to encourage unity under the banner of the Kiai. The concept of jihad and patience with all kinds of contextualization in dealing with the problems of followers' lives, becomes a powerful weapon for Kiai to get the attention of his followers, as well as become a kind of 'hammer mace' for others because of the authority attached to Kiai in revealing religious language that is not owned by other kind of leaders. 
The visibility of religion in the context of this Kiai power is seen as having massive potential for social transformation. The language of religion becomes the power of Kiai to move followers in one command; make something that was originally seen as profane into a sacred one; make something that was originally seen only as a mechanism of life into a living belief. It is not found in the life of secular society in Europe.

In leading the people, the NU Kiai is based on views formed by science. Performed by the intellect in building the civilization of the people, not by an ideology [51]. In contrast to other Islamic groups, NU Kiai develops their scientific tradition perfectly. It is because of the teachings of tauhid, fiqh and tasawuf [52]. These three traditions become three main things in considering the future of the human relationship with others. Kiai is responsible to God (tauhid) in carrying out the mandate to manage (fiqh) the world for the sake of mutual welfare in a wise way (tasawuf) [53].

From these three teachings, Kiai gives meaning to social practices aiming at maslahah (common good), the main concept that is at the core of every set of laws and policies in leading the people. In setting the direction and carrying out the decree towards the maslahah cannot be separated from the considerate attitudes, including tawasuth (moderate) tawazun (balanced), tasamuh (tolerant), i'tidal (fair) [54]. At the same time in creating peace of the nation and the world, it is very important to understand the concepts proposed by Kiai Ahmad Siddiq, namely ukhuwah Islamiyah (Islamic brotherhood), ukhuwah watoniyah (national brotherhood), and ukhuwah basyariyah (brotherhood of humanity) [55].

These guidelines and means are believed to be principles in leading followers in a mannered, peaceful, dignified, and civilized manner. So, the idea realizes the "representative" of Allah's will in the form of community welfare and religiosity following the concept echoed about izzul Islam wal muslimin (the might of Islam and Muslimin) [56]. These principles are what distinguish the movement of the Kiai from other Islamic movements, especially those in the Middle East. The principle of Kiai through hereditary teachings is to focus on the welfare of followers both spiritually and socially.

\section{CONCLUSION}

Some lessons to conclude here: first, the frame built on the community of Islamic traditionalism in challenging the situation around it is still dominated by leaders, so the goals, perceptions, and social logic formed in the community are part of the disposition of the community leader. Second, the wave of modernization and industrialization had an impact on the birth of a variety of Islamic traditionalist communities in terms of their form, response, and characteristics. Third, although there are differences in response to the wave of social change of modern society, there is a similarity of strategy, namely religious communication to strengthen the goals, narratives, capital, and actions of Islamic traditionalism communities, as well as being a tool to break the authority of other leaders. Fourth, Kiai as the leader of the Islamic traditionalism community can express the language of religiousness into the social space so that it becomes a force in mobilizing the mass and carrying out social transformation. The language of religion becomes the power of Kiai to move followers, as well as legitimize something from profane to sacred; From a living mechanism to a life's belief. It is not found in the context of secular societies in Europe that places Kiai as a religious leader as well as a social leader.

\section{REFERENCES}

[1] G. Brown, "Civic Islam: Muhammadiyah, NU and the Organisational Logic of Consensusmaking in Indonesia," Asian Stud. Rev., vol. 43, no. 3, pp. 397-414, 2019, doi: https://doi.org/10.1080/10357823.2019.1626 802.

[2] M. S. Visakh, R. Santhosh, and C. K. Mohammed Roshan, "Islamic Traditionalism in a Globalizing World: Sunni Muslim identity in Kerala, South India," Mod. Asian Stud., vol. 55, no. 6, pp. 2046-2087, Nov. 2021, doi: $10.1017 /$ S0026749X20000347.

[3] H. Rane and A. Duderija, "Muslim typologies in Australia: Findings of a national survey," Contemp. Islam, vol. 15 , no. 3, pp. 309-335, Nov. 2021, doi: 10.1007/s11562-021-004733.

[4] R. Azharghany, H. Siahaan, and A. Muzakki, "Alliance of Ummah in Rural Areas: A New Perspective on Islamic Populism in Indonesia," Relig. J. Stud. Agama-Agama dan Lintas Budaya, vol. 4, no. 4, pp. 239-250, 2020, doi: https://doi.org/10.15575/rjsalb.v4i4.10476.

[5] S. Pektas, "A comparative analysis of three Sunni Muslim organizations on 'moderate' and 'radical' Islam in Egypt, Morocco and Indonesia," Religion, vol. 51, no. 2, pp. 190213, Apr. 2021, doi: 10.1080/0048721X.2020.1868383.

[6] L. Schmidt, "Aesthetics of authority: 'Islam Nusantara' and Islamic 'radicalism' in Indonesian film and social media," Religion, 
vol. 51, no. 2, pp. 237-258, Apr. 2021, doi: 10.1080/0048721X.2020.1868387.

[7] F. M. Yunus and M. H. Amiruddin, "Tension Between Schools of Thought: Aswaja and Wahabi in Aceh," J. Ilm. Islam Futur., vol. 21, no. 2, p. 183, Aug. 2021, doi: 10.22373/jiif.v21i2.6039.

[8] R. Azharghany, "Konsumsi Yang-Sakral: Amalan dan Air Doa sebagai Terapi Religius Di Probolinggo," AT-TURAS J. Stud. Keislam., vol. 7, no. 1, pp. 138-178, Jun. 2020, doi: 10.33650/at-turas.v7i1.932.

[9] M. Van Bruinessen and F. Wajdi, "Syu' un Ijtima, iyah and the Kiai Rakyat: Traditionalist Islam , Civil Society and Social Concerns," Indones. Transit., pp. 205-248, 2006.

[10] A. Said Ali, Pergolakan di Jantung Tradisi: NU yang Saya Amati. Jakarta: LP3ES, 2008.

[11] H. Razaq dkk, Selayang Pandang Pondok Pesantren Nurul Jadid, 4th ed. Probolinggo: Bagian Humas dan Protokuler Sekretariat Pondok Pesantren Nurul Jadid, 2018.

[12] C. Kafabie, Sang Pejuang; Kisah Inspiratif Dua Tokoh Nurul Qodim. Probolinggo: Nurul Qodim Press, 2019.

[13] S. M. Noorhayati, "Redesain Paradigma Pendidikan Islam Toleran Dan Pluralis Di Pondok Pesantren (Studi Konstruktivisme Sikap Kiai dan Sistem Nilai di Pondok Pesantren Nurul Jadid, Paiton, Probolinggo)," UIN Sunan Ampel J. Islam. Educ., vol. 5, no. 1, pp. 1-20, 2017, doi: 10.15642/jpai.2017.5.1.1-20.

[14] M. I. M Ishaq, "KH. Abdul Wahid Zaini dan pengembangan pondok pesantren Nurul Jadid Paiton Probolinggo." Universitas Islam Negeri Sunan Ampel Surabaya, Surabaya, pp. 102-127, 2018, [Online]. Available: http://digilib.uinsby.ac.id/id/eprint/22412.

[15] N. C. Hafazah, "Modernisasi Pondok Pesantren Nurul Jadid Paiton Probolonggo pada Masa KH. Wahid Zaini Tahun 19842000.” Institut Agama Islam Negeri Jember, Jember, p. 98, 2020, [Online]. Available: http://digilib.iain-jember.ac.id/id/eprint/2141.

[16] A. Afif, "Peran Kiai dan Pemberdayaan Ekonomi Petani Tembakau di Kecamatan Paiton Probolinggo." Universitas Islam Negeri Sunan Ampel Surabaya, Surabaya, p. 47, 2021, [Online]. Available: http://digilib.iain-jember.ac.id/id/eprint/2752.

[17] Y. ILFATUF F, "Perubahan Jenis Pekerjaan Pada Masyarakat Sekitar Industri PLTU Paiton (Studi Pada Masyarakat Desa Binor, Kecamatan Paiton, Kabupaten Probolinggo).” University of Muhammadiyah Malang, p. 153,
2011, [Online]. Available: http://eprints.umm.ac.id/id/eprint/32009.

[18] R. F. E. Pradani, B. H. Purnomo, and B. Suyadi, "Dampak Pembangunan Pembangkit Listrik Tenaga Uap (PLTU) Paiton Terhadap Kondisi Sosial Ekonomi Masyarakat Desa Binor."." Tidak Dipublikasikan. Skripsi. Jember: FKIP Pendidikan Ekonomi, pp. 205220, 2014, [Online]. Available: http://repository.unej.ac.id/handle/123456789 164050.

[19] M. Mustofa and R. D. B. Sagara, "Analisis Persepsi Masyarakat Terhadap Aktivitas PLTU (Pembangkit Listrik Tenaga Uap) Paiton di Kecamatan Paiton Kabupaten Probolinggo," Relasi J. Ekon., vol. 11, no. 1, pp. 39-45, 2015, doi: https://doi.org/10.31967/relasi.v11i1.64.

[20] S. Bagus dkk., Kecamatan Paiton dalam Angka 2020. Probolinggo: BPS Kabupaten Probolinggo, 2020.

[21] E. Goffman, "Frame Analysis: An Essay on the Organization of Experience." Harper \& Row, New York, 1974.

[22] T. Parsons, The Structure of Social Action. New York: Free press, 1949.

[23] D. Ciurel, "The framing of protest," Prof. Commun. Transl. Stud., no. 11, pp. 7-15, 2018,

doi: https://doi.org/10.1017/S0007123419000413.

[24] R. D. Benford and D. A. Snow, "Framing processes and social movements: An overview and assessment," Annu. Rev. Sociol., vol. 26, no. 1, pp. 611-639, 2000, doi: https://doi.org/10.1146/annurev.soc.26.1.611.

[25] A. G. William, "The Social Psychology of Collective Action," in Frontiers in Social Movement Theory, A. D. Morris and C. McClurg Mueller, Eds. New Haven: Yale University, 1992, pp. 53-76.

[26] T. E. Nelson, Emphasis framing and political decision making. 2019.

[27] R. J. Norris, "Framing DNA: Social movement theory and the foundations of the innocence movement," J. Contemp. Crim. Justice, vol. 33, no. 1, pp. 26-42, 2017, doi: https://doi.org/10.1177/1043986216673014.

[28] W. P. Smith, "Social Movement Framing Tasks and Contemporary Racisms: Diagnostic and Prognostic Forms," Sociol. Race Ethn., vol. 7, no. 2, pp. 194-207, 2021, doi: https://doi.org/10.1177/2332649220922564.

[29] H. T. Duong, H. T. Vu, and N. Nguyen, “Activists' strategic communication in an authoritarian setting: Integrating social movement framing into issues management," Int. J. Strateg. Commun., vol. 13, no. 2, pp. 
133-151, 2019, doi: https://doi.org/10.1080/1553118X.2019.1590 366.

[30] R. K. Yin, Studi Kasus: Desain dan Metode. Jakarta: PT.Raja Grafindo Persada, 1996.

[31] P. Bourdieu, "Participant Objectivation," Source J. R. Anthropol. Inst., vol. 9, no. 2, pp. 281-294, 2003, doi: https://doi.org/10.1111/1467-9655.00150.

[32] M. and K. S. Alvesson, Reflexive Methodology: New Vistas for Qualitative Research. London: SAGE Publication Inc., 2000.

[33] R. Azharghany, "Konstruksi Sosial Terhadap Kiai Dalam Tradisi Air Doa dan Amalan," Universitas Muhammadiyah Malang, 2016.

[34] A. Chalik, Nahdlatul Ulama dan Geopolitik; Perubahan dan Kesinambungan. Yogyakarta: IMPULSE \& Buku Pintar kerjasama dengan IAIN Sunan Ampel Surabaya, 2011.

[35] P. Satrio, "Transmisi Budaya dan Identitas Sosial Pada Masyarakat Pendalungan,” 2019.

[36] A. Sutarto, "Sekilas Tentang Masyarakat Pendalungan," Yogyakarta, 2006.

[37] P. Bourdieu, Distinction: A social critique of the judgement of taste. Cambridge: Harvard University Press, 1984.

[38] R. Jenkins, Key Sociologists Pierre Bourdieu. New York: Routledge, 1992.

[39] J. Webb, T. Schirato, and G. Danaher, Understanding Bourdieu (Series: Cultural Studies). Crows Nest: Allen \& Unwin, 2002.

[40] R. B. Matibayeva and Z. Islomov, "Relationship of Religion and Tradition in Central Asia," Int. J. Innov. Eng. Manag. Res., vol. 9, no. 12, pp. 92-96, 2020, doi: DOI: 10.48047/IJIEMR/V09/I12/17.

[41] P. Bourdieu, Language and Symbolic Power. Cambridge: Polity Press, 1991.

[42] K. Lundby, "Public Religion in Mediatized Transformations," in Institutional Change in the Public Sphere, F. Engelstad, H. Larsen, J. Rogstad, K. Steen-Johnsen, D. Polkowska, A. S. Dauber-Griffin, and A. Leverton, Eds. De Gruyter, 2017.

[43] M. McGuire, Religion - the social context. Belmont: Wadsworth Publications Co, 1997.

[44] P. Bourdieu, The logic of practice. stanford: Stanford University Press, 1992.

[45] T. Hjelm, Is God back? : reconsidering the new visibility of religion. London: Bloomsbury Academic, 2015.
[46] P. L. Berger, The Sacred Canopy: Element of a Sociological Theory of Religion. New York: Anchor Books, 1969.

[47] P. L. Berger, "The Desecularization of the World: A Global Overview," in The Desecularization of the World: Resurgent Religion and World Politics, P. L. Berger, Ed. Grand Rapids: Eerdmans, 1999.

[48] V. R. Hadiz, Islamic populism in Indonesia and the Middle East. London: Cambridge University Press, 2016.

[49] R. Adiwilaga, M. U. Mustofa, and M. R. T. Rahman, "Quo Vadis Islamic Populism? An Electoral Strategy," Cent. Eur. J. Int. Secur. Stud., vol. 13, no. 4, 2019, doi: https://doi.org/10.200609/ijsoc.v2i4.234.

[50] D. Nur Syam, "Kyai, Santri dan Politik," http://nursyam.uinsby.ac.id/?p=17, 2019. .

[51] M. J. Maula, "Kembali ke Khittah 1945: Negara Republik Indonesia adalah 'Negara Islam'nya Umat Islam Indonesia Menurut NU," in Khittah dan Khidmah: Kumpulan Tulisan Majma' Buhuts An Nahdliyah, M. B. A. Hatani, Ed. Pati: Majma Buhuts An Nahdliyah, 2014.

[52] G. Barton, "The Gülen Movement, Muhammadiyah and Nahdlatul Ulama: Progressive Islamic Thought, Religious Philanthropy and Civil Society in Turkey and Indonesia," Islam Christ. Relations, vol. 25, no. 3, pp. 287-301, 2014, doi: $10.1080 / 09596410.2014 .916124$.

[53] R. Bush and G. Fealy, "The political decline of traditional Ulama in Indonesia: The state, Umma and Nahdlatul Ulama," Asian J. Soc. Sci., vol. 42, no. 5, pp. 536-560, Jan. 2014, doi: $10.1163 / 15685314-04205004$.

[54] Tim PW LBM NU Jawa Timur, Islam Nusantara; Manhaj Dakwah Islam Aswaja di Nusantara. Surabaya: PW LTN NU Jawa Timur, 2018.

[55] A. Feillard, "Nahdlatul Ulama in Indonesia," in Oxford Handbook of Islam and Politics, 2013.

[56] M. Z. Abidin, "Ulama in Indonesian Urban Society: A View of Their Role and Position in the Change of Age," J. Theol., vol. 28, no. 2, pp. 235-254, 2017, doi: 10.21580/teo.2017.28.2.1863. 